\title{
STATUS HEMATOLOGIK AYAM SENTUL DENGAN PENAMBAHAN EKSTRAK KULIT MANGGIS (Garcinia mangostana L.) YANG DISUPLEMENTASI Cu DAN Zn DALAM RANSUM
}

\author{
Avita Alawiyah*1, Lovita Adriani², Denny Rusmana ${ }^{2}$ \\ ${ }^{1}$ Program StudiIlmuPeternakan, FakultasPeternakan, UniversitasPadjadjaran Bandung \\ KampusJatinangor, Jl. Raya Bandung-Sumedang KM.21, Jatinangor, Sumedang, \\ Jawa Barat 45363 \\ ${ }^{2}$ Laboratorium FisiologiTernakdanBiokimia, DepartemenNutrisiTernakdanTeknologiPakan, \\ FakultasPeternakan, UniversitasPadjadjaran, Bandung \\ KampusJatinangor, J1. Raya Bandung- Sumedang KM.21, Jatinangor, Sumedang, \\ Jawa Barat 45363
}

Corresponding author : haryantikae@gmail.com
ABSTRAK : Penelitian bertujuan untuk mengetahui pengaruh penambahan ekstrak buah manggis yang disuplementasi dengan $\mathrm{Cu}$ dan $\mathrm{Zn}$ dalam ransum terhadap jumlah eritrosit, kadar hemoglobin, dan nilai hematokrit ayam sentulfase layer. Penelitian menggunakan 40 ekor ayam sentul betina, dan dipelihara dari umur 28 minggu sampai 35 minggu yang bertempat di Test Farm Fakultas Peternakan, Universitas Padjadjaran. Analisis Sampel dilakukan di Laboratorium Fisiologi Ternak dan Biokimia, Fakultas Peternakan Universitas Padjadjaran. Metode yang digunakan adalah eksperimental dengan Rancangan Acak Lengkap (RAL). Perlakuan terdiridari lima macam dengan empat ulangan, yaitu, $\mathrm{P} 0=$ ransum basal, $\mathrm{P} 1=$ ransum basal $+60 \mathrm{mg} / \mathrm{kg}$ ransum ekstrak kulit manggis $+\mathrm{Cu} 0,3 \mathrm{mg}$ dan $\mathrm{Zn} \mathrm{2,4} \mathrm{mg} ; \mathrm{P} 2=$ ransum basal $+120 \mathrm{mg} / \mathrm{kg}$ ransum ekstrak kulit manggis $+\mathrm{Cu} 0,6 \mathrm{mg}$ dan $\mathrm{Zn} \mathrm{4,8} \mathrm{mg} ; \mathrm{P} 3=$ ransum basal $+180 \mathrm{mg} / \mathrm{kg}$ ransum ekstrak kulit manggis $+\mathrm{Cu} 0,9 \mathrm{mg}$ dan $\mathrm{Zn} \mathrm{7,2} \mathrm{mg} ; \mathrm{P} 4=$ ransum basal $+240 \mathrm{mg} / \mathrm{kg}$ ransum ekstrak kulit manggis $+\mathrm{Cu} 1,2 \mathrm{mg}$ dan $\mathrm{Zn} \mathrm{9,6} \mathrm{mg.} \mathrm{Hasil} \mathrm{penelitian} \mathrm{menunjukan} \mathrm{bahwa} \mathrm{pemberian}$ ekstrak kulit manggis yang disuplementasi $\mathrm{Cu}$ dan $\mathrm{Zn}$ memberikan pengaruh tidak berbeda nyata $(\mathrm{P}>0.05)$. Disimpulkan bahwa, penambahan ekstrak kulit manggis yang disuplementasi dengan $\mathrm{Cu}$ dan $\mathrm{Zn}$ mampu mempertahankan jumlah eritrosit, kadar hemoglobin, dan nilai hematokrit berada pada kisaran normal.

Kata Kunci : ekstrak kulit manggis,Tembaga, Seng, hematologik

ABSTRACT : The research was conducted to know the effect of mangosteen peel extract supplemented with $\mathrm{Cu}$ and $\mathrm{Zn}$ in ration on the amount erythrocites, hemoglobin, and hematocrit value of sentul chicken layer phase. The research used 40 female sentul chickens and maintained from 28 weeks to 35 weeks at the Test Farm Animal Husbandry faculty, UniversitasPadjadjaran. Samples analyzed at the Laboratory Animal Physiology and Biochemistry, Faculty of Animal Husbandry Padjadjaran University. The methods used experimental with Completely Randomized Design (CRD). The treatment consisted of five kind with five repetitions, $P 0=$ basal ration, $P 1=$ basal rations $+60 \mathrm{mg} / \mathrm{kg}$ mangosteen peel extract $+\mathrm{Cu} 0,3 \mathrm{mg}$ and $\mathrm{Zn} \mathrm{2,4} \mathrm{mg}, P 2=$ basal rations $+120 \mathrm{mg} / \mathrm{kg}$ mangosteen peel extract $+\mathrm{Cu} 0,6 \mathrm{mg}$ and $\mathrm{Zn} \mathrm{4,8} \mathrm{mg}, P 3=$ basal rations $+180 \mathrm{mg} / \mathrm{kg}$ mangosteen peel extract $+\mathrm{Cu} 0,9 \mathrm{mg}$ and $\mathrm{Zn} \mathrm{7,2} \mathrm{mg}$, andP4 = basal rations +240 $\mathrm{mg} / \mathrm{kg}$ mangosteen peel extract $+\mathrm{Cu} 1,2 \mathrm{mg}$ and $\mathrm{Zn} \mathrm{9,6} \mathrm{mg}$. The results showed that the effect of giving mangosteen peel extract supplementedwith $\mathrm{Cu}$ and $\mathrm{Zn}$ had not significant effect $(P<0,05)$. The conclusion is the addition of mangosteen peel extract supplemented with $\mathrm{Cu}$ and $\mathrm{Zn}$ was able to maintain the amount of erithrocytes, hemoglobin, and hematocrit values in the normal range.

Keywords:mangosteen peel extract, Copper, Zinc, hematologic 


\section{PENDAHULUAN}

Ayam Sentul merupakan ayam lokal dari Kabupaten Ciamis Jawa Barat. Ayam sentul dipelihara secara semi intensif (Mushawwir dkk., 2020a,b). Ayam Sentul mempunyai keunggulan yaitu sebagai penghasil daging dan telur (tipe dwiguna), juga memiliki pertumbuhan yang relatif cepat (Kurnia, 2011). Menurut Widjastuti (1996) dalam satu periode peneluran ayam sentul menghasilkan telur sebanyak 10-18 butir, fertilitas diatas $80 \%$ dan daya tetastinggi yaitu $70-80 \%$.

Produktivitas ternak dapat berlangsung dengan optimal jika kondisi fisiologis suatu ternak berjalan dengan baik. Kondisi fisiologis yang baik erat kaitannya dengan kondisi kesehatan ternak. Kondisi fisiologis pada ternak sangat dipengaruhi oleh lingkungan, manajemen, nutrisi pakan dan iklim. Profil darah (hematologis) dapat dijadikan sebagai screening test (model pengujian) untuk melihat kondisi fisiologis suatu ternak yang nantinya dihubungkan dengan status kesehatannya untuk meningkatkan produktivitas.

Produksi eritrosit dipengaruhi oleh tinggi rendahnya kandungan oksigen dimana protein penginduksi akan menginduksi pertumbuhan dan diferensiasi sehingga produksi eritrosit akan meningkat (Sturkie, 1998). Kisaran normal jumlah eritrosit pada ayam berada pada kisaran 2,3-3,5 x $10^{6} / \mathrm{mm}^{3}$ (Darmawan, 2001).

Hemoglobin merupakan petunjuk kecukupan oksigen yang diangkut. Kadar hemoglobin dipengaruhi oleh kadar oksigen dan jumlah eritrosit, sehingga ada kecenderungan jika jumlah eritrosit rendah, maka kadar hemoglobin akan rendah dan jika oksigen dalam darah rendah, maka tubuh terangsang meningkatkan produksi eritrosit dan hemoglobin (Schalm, 2010). Jain (1993) menyatakan bahwa kadar normal hemoglobin ayam yaitu $7,0-13,0 \mathrm{~g} / \mathrm{dl}$.

Nilai hematokrit berhubungan positif dengan jumlah eritrosit dan kadar hemoglobin. Apa bila nilai eritrosit meningkat maka hematokrit dan hemoglobin akan meningkat dan sebaliknya jika nilai eritrosit mengalami penurunan maka hematokrit dan hemoglobin juga akan menurun (Meyer dan Harvey, 2004). Jumlah hematokrit pada ayam berturut-turut adalah 22-35\% (Jain, 1993).

Komponen penyusun membrane sel adalah asam lemak tak jenuh majemuk yang secara alami mudah sekali teroksidasi menghasilkan berbagai senyawa radikal bebas. Proses oksidasi tersebut menyebabkan kadarasam lemak esensial pada membran plasma menjadi berkurang dan permeabilitas membrane terganggu sehingga radikal bebas menjadi makin mudah menerobos masuk ke dalam sel dan mengakibatkan berbagai kerusakan. Kerusakan membrane dapat menyebabkan lepasnya senyawa hemoglobin dari eritrosit. Salah satu upaya untuk mempertahankan jumlah eritrosit, kadar hemoglobin, dan nilai hematokrit dalam keadaan normal dapat dilakukan dengan menggunakan ransum yang dicampur dengan antioksidan alami (Kamil dkk., 2020; Mushawwir dkk., 2021) berupa xantone, yang merupakan kandungan dari ekstrak kulit manggis (Garcinia mangostana L.)

Senyawa xanthone merupakan substansi kimia alami yang bersifat sebagai immune modulator yang bisa menstabilkan sel-sel di dalam tubuh serta dapat membantu dalam proses pembentukan eritrosit. Xanthone mampu mengikat oksigen bebas yang tidak stabil yaitu radikal bebas perusak sel di dalam tubuh sehingga xanthone dapat menghambat proses degenerasi (kerusakan) sel (Mushawwir dkk, 2020e).

Ekstrak kulit manggis perlu di tambahkan mineral mikro $\mathrm{Cu}$ dan $\mathrm{Zn}$ untuk menstabilisasi rantai ikatan menjadi rantai ikat silang. Rantai ikat pendek molekul organik dari ekstrak kulit manggis membentuk komponen siklik dengan ion logam (Chowdhury dan Chandra, 1987). Mineral $\mathrm{Cu}$ dan Zn berperan sebagai pelindung bioaktivitas yang ada di dalam ekstrak kulit manggis, sehingga ionisasi dalam saluran pencernaan semakin tinggi.

Penetapan dosis pada penelitian ini mengacu pada penelitian yang telah dilakukan oleh Siregar dkk. (2020) dan Jiwandini dkk. (2020) menggunakan ekstrak alamiah dengan dosis sebesar $200 \mathrm{mg} / \mathrm{kg} \mathrm{BB}$, atau jika dikonversi menjadi $0,02 \% \mathrm{~kg}$ BB ransum yang diberikan pada ayam broiler dapat menghasilkan nilai hematologi yang optimal dan masih aman digunakan.

\section{METODE PENELITIAN}

\section{Ternak Percobaan}

Ternak yang digunakan dalam penelitian yaitu ayam sentul fase layer sebanyak 40 ekor dipelihara dari umur 28 minggu sampai 35 minggu. Kandang yang digunakan yaitu kandang baterai dengan system cage. Satu cage diisi dengan satu ekor ayam, sehingga untuk pemeliharaan ayam sentul membutuhkan 40 buah cage. 2 buah cage untuk satu perlakuan ayam. Masing-masing unit kandang berukuran $p x l \times t$ yaitu $40 \mathrm{~cm} \times 30 \mathrm{~cm} \times 21 \mathrm{~cm}$. Penelitian menggunakan metode eksperimental dengan Rancangan Acak Lengkap (RAL). Pemberian ransum yang mengandung ekstrak kulit manggis yang disuplementasi dengan $\mathrm{CuSO}_{4}$ dan $\mathrm{ZnO}$ dalam tingkat yang berbeda terhadap ayam Sentul. Ayam dibagi ke dalam 5 perlakuan dan setiap perlakuan diulang sebanyak 4 kali, yaitu ;

$\mathrm{P}_{0}$ : Ransum basal tanpa ekstrak kulit manggis

$P_{1}$ : Ransum basal $+60 \mathrm{mg} / \mathrm{kg}$ ekstrak kulit manggis yang disuplementasi $\mathrm{Cu}, \mathrm{Zn}$

$\mathrm{P}_{2}$ : Ransum basal $+120 \mathrm{mg} / \mathrm{kg}$ ekstrakkulitmanggis yang disuplementasi $\mathrm{Cu}, \mathrm{Zn}$ 
$\mathrm{P}_{3}$ : Ransum basal $+180 \mathrm{mg} / \mathrm{kg}$ ekstrak kulit manggis yang disuplementasi $\mathrm{Cu}, \mathrm{Zn}$

$\mathrm{P}_{4}$ : Ransum basal $+240 \mathrm{mg} / \mathrm{kg}$ ekstrak kulit manggis yang disuplementasi $\mathrm{Cu}, \mathrm{Zn}$

\section{Pembuatan Ekstrak Kulit Manggis}

Prosedur pembuatan ekstrak kulit manggis yaitu, Sampel $7.000 \mathrm{~g}$ kulit manggis segar, dikeringkan dan dipotong kecil-kecil. Sampel daun kepel kering ditimbang sebanyak $5.000 \mathrm{~g}$. Kemudian dimaserasi dengan etanol 96\% selama 24 jam. Ekstrak etanol 96\% hasil maserasi disaring dengan kertas saring dan ditampung filtratnya. Filtrat tersebut selanjutnya dievaporasi menggunakan alat rotary evaporator pada suhu \pm $62^{\circ} \mathrm{C}$ sehingga diperoleh ekstrak pekat etanol 4,471 g. Setelah itu, bahan yang sudah kental tersebut dibawa ke oven dengan suhu $60^{\circ} \mathrm{C}$ dan didapatkan serbuk ekstrak kulit manggis sebesar 3,621 g. Ekstrak kulit manggis kemudian disuplementasi menggunakan $\mathrm{Cu}$ dan $\mathrm{Zn}$.

\section{Analisis Statistika}

Data yang diperoleh dianalisis secara statistic dengan model matematika dari Rancangan Acak Lengkap. Model Matematikanya sebagai berikut :

Hipotesis :

$$
Y_{i j}=\mu+\tau_{i}+\varepsilon_{i j}
$$

$\mathrm{H}_{0}: \mathrm{P}_{3} \leq\left(\mathrm{P}_{0}, \mathrm{P}_{1}, \mathrm{P}_{2}, \mathrm{P}_{4}\right)$ (tidak ada pengaruh perlakuan pada jumlah eritrosit, kadar hemoglobin, dan nilai hematokrit)

$\mathrm{H}_{1}: \mathrm{P}_{3}>\left(\mathrm{P}_{0}, \mathrm{P}_{1}, \mathrm{P}_{2}, \mathrm{P}_{4}\right)$ (paling sedikit ada satu perlakuan yang mepengaruhi pada jumlah eritrosit, kadar hemoglobin, dan nilai hematokrit)

Data yang diperoleh telah dianalisis dengan software SPSS IBM 21.

\section{HASIL DAN PEMBAHASAN}

\section{Pengaruh Perlakuan terhadap Eritrosit}

Rataan jumlah eritrosit pada penelitian ayam sentul yang diberi ekstrak kulit manggis dan disuplementasi $\mathrm{Cu}$ dan $\mathrm{Zn}$ dalam ransum dapat dilihat pada Tabel 1 .

Berdasarkan data Tabel 1. Menunjukan bahwa penggunaan ekstrak kulit manggis $60 \mathrm{mg}, 120 \mathrm{mg}$, $180 \mathrm{mg}$, dan $240 \mathrm{mg}$ yang telah disuplementasi $\mathrm{Cu}$ dan $\mathrm{Zn}$ dalam ransum, memberikan hasil rataan eritrosit ayam sentul berkisar 2,48-2,97 x $10^{6} / \mathrm{mm}^{3}$. Kisaran rataan jumlah eritrosit yang diperoleh dalam penelitian berada dalam kisaran normal yaitu 2,3-3,5 x $10^{6} / \mathrm{mm}^{3}$ (Latipudin $\mathrm{dkk}, 2011$ ). Hal ini menunjukan ayam sentul yang diberi ransum ekstrak kulit manggis suplementasi $\mathrm{Cu}$ dan $\mathrm{Zn}$ memiliki fisiologis yang sehat.

Hasil analisis ragam penggunaan ekstrak kulit manggis yang disuplementasi $\mathrm{Cu}$ dan $\mathrm{Zn}$ dalam ransum terhadap jumlah eritrosit ayam sentul memberikan pengaruh tidak nyata $(\mathrm{P}>0,05)$. Soehasono dkk. (2010) menyebutkan bahwa faktor yang mempengaruhi jumlah eritrosit antara lain umur, spesies, konsumsi ransum dan ketersediaan bahan produksi eritrosit. Jumlah eritrosit dapat pula dipengaruhi oleh senyawa-senyawa aktif dalam ransum pada konsentrasi yang tinggi. (Nijveldt, 2001) Penelitian terdahulu yang dilakukan oleh Ragil dkk (2016) menunjukkan bahwa pemberian ekstrak kulit buah manggis dalam ransum dapat memberikan hasil yang tidak berbeda nyata terhadap jumlah eritrosit ayam sentul.

Kenaikan jumlah eritrosit menunjukkan respon yang positif terhadap pengaruh zat xanthone yang terdapat dalam ekstrak kulit buah manggis, dimana xanthone merupakan senyawa aktif yang bersifat sebagai immune modulator, sehingga bisa

Tabel 1. Rataan jumlah eritrosit pada darah ayam sentul $\left(10^{6} / \mathrm{mm}^{3}\right)$

\begin{tabular}{|c|c|c|c|c|c|}
\hline \multirow[t]{2}{*}{ Ulangan } & \multicolumn{5}{|c|}{ Perlakuan } \\
\hline & $\mathrm{P} 0$ & $\mathrm{P} 1$ & $\mathrm{P} 2$ & P3 & $\mathrm{P} 4$ \\
\hline & \multicolumn{5}{|c|}{ - } \\
\hline 1 & 2,84 & 3,01 & 2,25 & 2,19 & 2,19 \\
\hline 2 & 3,16 & 2,59 & 3,28 & 2,60 & 3,18 \\
\hline 3 & 3,01 & 3,00 & 2,77 & 2,69 & 2,67 \\
\hline 4 & 2,89 & 3,12 & 2,64 & 2,47 & 2,71 \\
\hline Jumlah & 11,9 & 11,72 & 10,94 & 9,95 & 10,75 \\
\hline Rata-rata & 2,97 & 2,93 & 2,73 & 2,48 & 2,68 \\
\hline Standar Deviasi & 0,14 & 0,23 & 0,42 & 0,21 & 0,40 \\
\hline \multicolumn{6}{|c|}{$\begin{array}{l}\text { Keterangan : } \\
\mathrm{P}_{0}: \text { Ransum basal tanpa ekstrak kulit manggis } \\
\mathrm{P}_{1}: \text { Ransum basal }+60 \mathrm{mg} / \mathrm{kg} \text { ekstrak kulit manggis yang disuplementasi } \mathrm{Cu}, \mathrm{Zn} \\
\mathrm{P}_{2}: \text { Ransum basal }+120 \mathrm{mg} / \mathrm{kg} \text { ekstrak kulit manggis yang disuplementasi } \mathrm{Cu}, \mathrm{Zn} \\
\mathrm{P}_{3} \text { : Ransum basal }+180 \mathrm{mg} / \mathrm{kg} \text { ekstrak kulit manggis yang disuplementasi } \mathrm{Cu}, \mathrm{Zn} \\
\mathrm{P}_{4}: \text { Ransum basal }+240 \mathrm{mg} / \mathrm{kg} \text { ekstrak kulit manggis yang disuplementasi } \mathrm{Cu}, \mathrm{Zn}\end{array}$} \\
\hline
\end{tabular}


Tabel 2. Rataan Hemoglobin pada darah ayam Sentul

\begin{tabular}{|c|c|c|c|c|c|}
\hline \multirow{2}{*}{ Ulangan } & \multicolumn{5}{|c|}{ Perlakuan } \\
\hline & P0 & $\mathrm{P} 1$ & $\mathrm{P} 2$ & $\mathrm{P} 3$ & $\mathrm{P} 4$ \\
\hline & \multicolumn{5}{|c|}{ 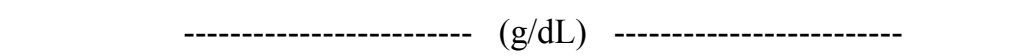 } \\
\hline 1 & 11 & 12 & 13,5 & 11 & 10 \\
\hline 2 & 10,5 & 9 & 10 & 12,2 & 11 \\
\hline 3 & 8 & 11 & 10,5 & 12 & 10,5 \\
\hline 4 & 8 & 12 & 10,5 & 11,5 & 8 \\
\hline Jumlah & 37,5 & 44 & 44,5 & 46,7 & 39,5 \\
\hline Rata-rata & 9,37 & 11 & 11,12 & 11,67 & 9,87 \\
\hline StandarDeviasi & 1,60 & 1,41 & 1,60 & 0,53 & 1,31 \\
\hline
\end{tabular}

Keterangan :

$\mathrm{P}_{0}$ :Ransum basal tanpa ekstrak kulit manggis

$\mathrm{P}_{1}$ :Ransum basal $+60 \mathrm{mg} / \mathrm{kg}$ ekstrak kulit manggis yang disuplementasi $\mathrm{Cu}, \mathrm{Zn}$

$\mathrm{P}_{2}$ :Ransum basal $+120 \mathrm{mg} / \mathrm{kg}$ ekstrak kulit manggis yang disuplementasi $\mathrm{Cu}, \mathrm{Zn}$

$\mathrm{P}_{3}$ : Ransum basal $+180 \mathrm{mg} / \mathrm{kg}$ ekstrak kulit manggis yang disuplementasi $\mathrm{Cu}, \mathrm{Zn}$

$\mathrm{P}_{4}$ : Ransum basal $+240 \mathrm{mg} / \mathrm{kg}$ ekstrak kulit manggis yang disuplementasi $\mathrm{Cu}, \mathrm{Zn}$

Berdasarkan data Tabel 2. Menunjukan bahwa penggunaan ekstrak kulit manggis $60 \mathrm{mg}, 120 \mathrm{mg}$, $180 \mathrm{mg}$, dan $240 \mathrm{mg}$ yang telah disuplementasi $\mathrm{Cu}$ dan $\mathrm{Zn}$ dalam ransum, memberikan hasil rataan kadar hemoglobin ayam sentul berkisar antara 9,37-11,67 g/dL, dengan rataan masing-masing perlakuan dari yang tertinggi ke terendah adalah $\mathrm{P} 3$ 11,67 g/dL, P2 11,12 g/dL, P1 11 g/dL, P4 9,87 $\mathrm{g} / \mathrm{dL}, \quad$ P0 $9,37 \mathrm{~g} / \mathrm{dL}$. Kisaran rataan jumlah hemoglobin yang diperoleh dalam penelitian berada dalam kisaran normal yaitu 7,0-13,0 g/dL (Jain, 1993).

Hasil analisis ragam penggunaan ekstrak kulit manggis yang disuplementasi $\mathrm{Cu}$ dan $\mathrm{Zn}$ dalam ransum terhadap jumlah hemoglobin ayam sentul memberikan pengaruh tidak nyata $(\mathrm{P}>0,05)$. Penggunaan ekstrak kulit manggis yang disuplementasi $\mathrm{Cu}$ dan $\mathrm{Zn}$ dosis $60 \mathrm{mg} / \mathrm{kg}(\mathrm{P} 1)$, $120 \mathrm{mg} / \mathrm{kg}$ (P2), $180 \mathrm{mg} / \mathrm{kg}$ (P3), $240 \mathrm{mg} / \mathrm{kg}$ (P4) dalam ransum tidak berbeda nyata dengan ransum kontrol, namun terjadi peningkatan rataan kadar hemoglobin ayam sentul yang diberi perlakuan. Seperti yang diungkapkan oleh Hernawan dkk. (2017) dan Jiwandini dkk. (2020), bahwa senyawa xanthone yang terkandung dalam kulit manggis memilki antioksidan yang tinggi serta bersifat immune modulator yang bisa menstabilkan sel-sel di dalam tubuh, serta juga dapat membantu dalam proses pembentukan eritrosit dan hemoglobin.

Hemoglobin di dalam eritrosit memungkinkan timbulnya kemampuan untuk mengangkut oksigen, serta menjadi penyebab timbulnya warna merah pada darah (Frandson, 1992). Penurunan dan kenaikan hemoglobin dipengaruhi oleh pembentukan eritrosit (erythropoiesis), sehingga nilai eritrosit dan hemoglobin berbanding lurus. Sesuai pernyataan Adriani dkk. (2015) bahwa hemoglobin merupakan bagian dari eritrosit yang berfungsi dalam mengikat oksigen untuk diedarkan keseluruh tubuh, maka peningkatan kadar hemoglobin berbanding lurus dengan peningkatan jumlah eritrosit. Disampaikan pula oleh Mushawwir dkk. (2019a,b) bahwa kadar hemoglobin dipengaruhi oleh kadar oksigen dan jumlah eritrosit, jika jumlah eritrosit rendah, maka kadar hemoglobin akan rendah dan jika oksigen dalam darah rendah, maka tubuh terangsang meningkatkan produks ieritrosit dan hemoglobin. Menurut Soeharsono (2010) setiap eritrosit mengandung \pm 180 juta molekul hemoglobin, satu molekulnya dapat mengikat 4 molekul oksigen.

Seng (Zn) dalam sistem biologis merupakan komponen metaloenzym seperti polymerase DNA, peptidese karboksi $A$ dan $B$, dan phosphatase alkalin (Larvor 1983). Enzim tersebut berperan pada poliferasi DNA yang selanjutnya berpengaruh pada sintesis protein, proses pencernaan protein dan absorpsi asam amino, serta metabolisme energy (Nijvelstd dkk. 2001; Mushawwir dkk. 2010). Aktivitas enzim tersebut terganggu apabila defisiensi Zn (Sadiah dkk., 2015).

Hati merupakan organ utama tempat penyimpanan $\mathrm{Cu}$. Mineral $\mathrm{Cu}$ akan berikatan dengan protein membentuk enzim-enzim seperti seruloplasmin (Nurmalia dkk., 2020). Kualitas ransum yang disuplementasi $\mathrm{Cu}$ dapat memperbaiki sistem metabolisme dan proses fisiologik yang ada didalam tubuh ayam (Soeharsono dkk., 2010; Mushawwir dkk., 2019a,b). Tembaga berperan pada sintesis hemoglobin yang normal, merupakan komponen ceruloplasmin, dismutase superoksida (SOD),oksidase lysil dan oksidase sitokrom (Adriani dkk., 2018). Ceruloplasmin berperan dalam penyerapan dan transpor $\mathrm{Fe}$ yang dibutuhkan untuk sintesis hemoglobin dan dapat berfungsi 
Tabel 3. Rataan Hematokrit pada darah ayam Sentul

\begin{tabular}{|c|c|c|c|c|c|}
\hline \multirow{2}{*}{ Ulangan } & \multicolumn{5}{|c|}{ Perlakuan } \\
\hline & $\mathrm{P} 0$ & $\mathrm{P} 1$ & $\mathrm{P} 2$ & P3 & $\mathrm{P} 4$ \\
\hline & & ------ & $(\%)$ & ---- & \\
\hline 1 & 31 & 29 & 30 & 30 & 29 \\
\hline 2 & 30 & 27 & 26 & 31 & 33 \\
\hline 3 & 28 & 32 & 33 & 29 & 32 \\
\hline 4 & 30 & 29 & 31 & 28 & 30 \\
\hline Jumlah & 119 & 117 & 120 & 118 & 124 \\
\hline Rata-rata & 29,75 & 29,25 & 30 & 29.5 & 31 \\
\hline StandarDeviasi & 1,25 & 2,06 & 2,94 & 1,29 & 1,82 \\
\hline
\end{tabular}

Keterangan :

$\mathrm{P}_{0}$ :Ransum basal tanpa ekstrak kulit manggis

$\mathrm{P}_{1}$ :Ransum basal $+60 \mathrm{mg} / \mathrm{kg}$ ekstrak kulit manggis yang disuplementasi $\mathrm{Cu}, \mathrm{Zn}$

$\mathrm{P}_{2}$ :Ransum basal $+120 \mathrm{mg} / \mathrm{kg}$ ekstrak kulit manggis yang disuplementasiCu, $\mathrm{Zn}$

$\mathrm{P}_{3}$ : Ransum basal $+180 \mathrm{mg} / \mathrm{kg}$ ekstrak kulit manggis yang disuplementasiCu,Zn

$\mathrm{P}_{4}$ : Ransum basal $+240 \mathrm{mg} / \mathrm{kg}$ ekstrak kulit manggis yang disuplementasi $\mathrm{Cu}, \mathrm{Zn}$

sebagai antioksidan dan agen pertahanan (Sadiah dkk., 2015; Siregar dkk., 2020).

\section{Pengaruh Perlakuan terhadap Hematokrit}

Nilai hematokrit atau packed cell volume adalah suatu istilah yang artinya persentase (berdasar volume) dari darah yang terdiri dari sel darah merah (Frandson, 1996). Rataan kadar hematokrit pada penelitian ayam sentul yang diberi ekstrak kulit manggis yang disuplementasi $\mathrm{Cu}$ dan Zn dalam ransum, dapat dilihat pada Tabel 3.

Berdasarkan data Tabel 3. Menunjukan bahwa penggunaan ekstrak kulit manggis $60 \mathrm{mg}, 120 \mathrm{mg}$, $180 \mathrm{mg}$, dan $240 \mathrm{mg}$ yang telah disuplementasi $\mathrm{Cu}$ dan $\mathrm{Zn}$ dalam ransum, memberikan hasil rataan kadar hematokrit ayam sentul berkisar antara 29,25-31\%. Rataan kadar hematokrit ayam sentul masih dalam kisaran normal, yaitu 22-35\% (Jain, 1993). Hasil analisis ragam penggunaan ekstrak kulit manggis yang disuplementasi $\mathrm{Cu}$ dan $\mathrm{Zn}$ dalam ransum terhadap jumlah hematokrit ayam sentul memberikan pengaruh tidak nyata $(\mathrm{P}>0,05)$.

Secara normal, jumlah eritrosit berkorelasi positif dengan nilai hematokrit. Berdasarkan hasil ini tampak bahwa nilai hematokrit dengan jumlah eritrosit memiliki keterkaitan. Menurut Dawson dan Whittow (2000); Mushawwir dkk. (2020d); Nurmalia dkk. (2020); Tanuwian dkk. (2020) bahwa semakin besar jumlah eritrosit, maka semakin besar pula nilai hematokrit dalam darah. Begitu pun sebaliknya, penurunan nilai hematokrit dapat disebabkan oleh kerusakan eritrosit (Mushawwir dkk., 2020a,b,c,), penurunan produksi eritrosit atau dapat juga dipengaruhi oleh jumlah dan ukuran eritrosit. Besarnya nilai hematokrit dipengaruhi oleh bangsa dan jenis ternak, umur dan fase produksi ), jenis kelamin ternak, penyakit, serta iklim setempat (Sujono, 1991).
Peningkatan rataan hematokrit disebabkan karena jumlah xantone sebagai penyeimbang radikal bebas di dalam tubuh. Gamma mangostin dan Alfa-mangostin yang terkandung dalam kulit manggis menunjukan aktivitas scavenging radikal bebas. Xanthone melawan radikal bebas dengan cara mendonorkan atom hydrogen dari gugus hidroksil $(\mathrm{OH})$ kepada radikal bebas sehingga merubah radikal bebas menjadi lebih stabil (Rahmah, dkk., 2012; Mushawwir dkk., 2010; Suwarno dkk., 2019; Mushawwir dkk., 2021)

Setiap sel membutuhkan mineral Zn agar tetap hidup sehat dan dapat berfungsi dengan baik. Zinc merupakan komponen penting pada struktur dan fungsi membrane sel. $\mathrm{Zn}$ berfungsi sebagai antioksidan (Jiwandini dkk., 2019; Kamil dkk,. 2020), dan melindungi tubuh dari serangan peroksidase lipid (Lieberman \& Brunin, 1990; Mushawwir dkk., 2019a,b; Dinana dkk., 2019; Siregardkk., 2020). Mineral ini mampu menghambat terjadinya apoptosis (Truong-Tran et al. 2000; Tanuwiria dkk., 2020a,b).

\section{KESIMPULAN DAN SARAN}

Penggunaan ekstrak kulit manggis dosis 60 $\mathrm{mg} / \mathrm{kg}, 120 \mathrm{mg} / \mathrm{kg}, 180 \mathrm{mg} / \mathrm{kg}$, dan $240 \mathrm{mg} / \mathrm{kg}$ yang disuplementasi $\mathrm{Cu}$ dan $\mathrm{Zn}$ dalam ransum memberikan pengaruh positif, karena jumlah eritrosit, hemoglobin, dan hematokrit ayam sentul fase layer dalam range normal, yang menandakan bahwa fisiologis ayam sehat. Penulis merekomendasikan uji lanjut terhadap kualitas daging dan telur, agar produktivitas ayam sentul meningkat. 


\section{UCAPAN TERIMAKASIH}

Ucapan terima kasih disampaikan kepada Prof. Dr. Ir. Lovita Adriani, MS., sebagai pembimbing utama, dan kepada Dr. Ir. Denny Rusmana S.Pt., M.Si., IPM. Selaku pembimbing anggota, yang telah meluangkan waktu, tenaga dan pikirannya untuk membimbing, serta kepada Prof. Dr. Ir. Hj. Tuti Widjastuti, MS., selaku ketua tim ALG yang telah mengikut sertakan penulis dalam penelitian.

\section{DAFTAR PUSTAKA}

Adriani, L., A. Mushawwir, B.R. Anastasia, B. Rahayu. 2018. Effect of combination chitosan and turmeric powder (curcuma domestica val.) For improving blood lipid profile in broilers. Scientific Papers. Series D. Animal Science. LXI (1):225-229.

Adriani, L., B. Asri. Y., D. Rusmana. 2015. Pengaruh Pemberian Tepung Buah Mengkudu (Morindacitrifolia L.) Dalam Ransum Terhadap Nilai Hematologi Puyuh (Coturnix coturnix japonica) Fase Layer. J. Unpad. Vol 4 . No 4.

Adriani, L., A. Mushawwir. 2020. Correlation Between Blood Parameters, Physiological and Liver Gene Expression Levels in Native Laying Hens Under Heat Stress. IOP Conf. Series: Earth and Environmental Science. 466:1-7.

Dawson, W.R., and G.C. Whittow. 2000. Regulation of Body Temperature. Pages 343 379 in Sturkie's Avian Physiology. G. C. Whittow, ed. Academic Press, New York, NY.

Dinana, A., D. Latipudin, D. Darwis, A. Mushawwir. 2019. Profil Enzim Transaminase Ayam Ras Petelur Yang Diberi Kitosan Iradiasi. Jurnal Nutrisi Ternak Tropis dan Ilmu Pakan 1 (1):6-15.

Frandson, R. D. 1992. Anatomi dan Fisiologi Ternak, Edisi 4. Gajah Mada Press.Yogyakarta.

Hernawan, E., L. Adriani, A. Mushawwir, C. Cahyani, D. Darwis. 2017. Effect of dietary supplementation of chitosan on blood biochemical profile of laying hens. Pakistan Journal of Nutrition. 16(9):696-699.

Jain, N. C. 1993. Essential of Veterinary Hematology: Lea and Febiger, Philadelpia.

Jiwandini, A., Handi Burhanudin, A. Mushawwir. 2020.Kadar enzim transaminase (sgpt, sgot) dan gamma glutamyl transpeptidase $(\gamma$-gt) pada ayam petelur fase layer yang diberi ekstrak pegagan (Centellaasiatica). Jurnal Nutrisi Ternak Tropis dan Ilmu Pakan. 2(2):112-119

Kamil, K.A., D. Latipudin, A. Mushawwir, D. Rahmat, R. L. Balia. 2020. The Effects of Ginger Volatile Oil (GVO) on The Metabolic Profile of Glycolytic Pathway, Free Radical and Antioxidant Activities of Heat-Stressed Cihateup Duck. International Journal on Advanced Science, Engineering and Information Technology. 10:1228-1233

Kurnia, Y. 2011. Morfometrik Ayam Sentul, Kampung dan Kedu pada Fase Pertumbuhan dari Umur 1-12 Minggu. Skripsi. Program Alih Jenis. Departemen Produksi dan Teknologi Peternakan, Fakultas Peternakan, Institut Pertanian Bogor. Bogor.

Latipudin, D. dan A. Mushawwir, 2011. Regulasi Panas Tubuh Ayam Ras Petelur Fase Grower dan Layer, Jurnal Sains Peternakan Indonesia. 6(2) : 77-82.

Larvor, P. 1983. The Pools of Celluler Nutrients: Mineral. In: Dynamic Biochemistry of Animal Production. P. M. Riss. Ed. Elsevier. Amsterdam.

Lieberman S, Bruning N. 1990. The Real Vitamin and Mineral Book. A very publishing group inc garden city park, New York (US).

Meyer DJ \& Harvey JW. 2004. Veterinary Laboratory Medicine Interpretation \& Diagnosis. Ed 3rd. Saunders (US) : Saunders University Pr.

Mushawwir, A. Y.K. Yong, L. Adriani, E. Hernawan, K.A. Kamil. 2010. The Fluctuation Effect of Atmospheric Ammonia (NH3) Exposure and Microclimate on Hereford Bulls Hematochemical. J. of the Indon Tropical Anim Agric, 35:232-238.

Mushawwir, A., N. Suwarno, A.A. Yulianti, R. Permana. 2019a. Dampak Pemberian Minyak Atsiri Bawang Putih terhadap Histologi IlleumItik Cihateup Fase Pertumbuhan yang Dipelihara Sacara Ekstensif. Jurnal Peternakan Sriwijaya. 8(2):35-44.

Mushawwir, A., N. Suwarno, A.A. Yulianti. 2019b. Thermoregulasi Domba Ekor Gemuk yang Dipelihara pada Ketinggian Tempat (Altitude) yang Berbeda. Jurnal Ilmu dan Industri Peternakan. 5 (2):77-86.

Mushawwir, A., A.A. Yulianti, N. Suwarno, R. Permana. 2020a. Profil metabolit plasma darah dan aktivitas kreatin kinase sapi perah berdasarkan fluktuasi mikro klimat lingkungan kandangnya. J. Veteriner. 21:24-30.

Mushawwir, A., A.A. Yulianti, N. Suwarno. 2020 b. Histologi Liver Burung Puyuhdengan Pemberian Minyak Atsiri Bawang Putih. Jurnal Ilmu dan Teknologi Peternakan. 8(1):17.

Mushawwir, A., N. Suwarno, D. Latipudin. 2020c. Profil metabolic jalur glikogenolisis puyuh dalam kondisi stress panas dengan pemberian diallyl n-sulfida (dn-s) organic. J. Galung Tropika. 9:48-59.

Mushawwir, A., N. Suwarno, R. Permana. 2020d. Profil non-esterified fatty acids (NEFA) dan trigliserida ayam sentul pada sistem 
pemeliharaan berbeda. J. Ilmu dan Industri Peternakan. 6:14-24.

Mushawwir, A., N. Suwarno, R.Permana. 2020e. Profil Total Lemak dan Protein Hati Puyuh Fase Grower dan Layer. Jurnal Ilmu dan Industri Peternakan. 6(2):65-76.

Mushawwir, A., N.Suwarno, R. Permana. 2021. Dialil n-Sulfida Organik Menurunkan Kadar Lipid Plasma Darah dan Hati Itik Cihateup Fase Grower. Jurnal Ilmu dan Teknologi Peternakan Tropis. 8(1):19-25.

Nijveldt, R. J; E. V. Nood: D. V. Hoorn: P. G. Boelens: K. V. Norren: and P. V. Leewen. 2001. Flavonoids: a Review of Probable Mechanisms of Action and Potential Application 1-3. The American Journal of Clinical Nutrition. 418-425

Nurmalia, V.R., Denny Rusmana, Andi Mushawwir. 2020. Kadar Glukosa Dan Trigliserida Ayam Ras Petelur Fase Layer Yang Diberi Ransum Mengandung Ekstrak Pegagan (Centellaasiatica). Jurnl Ilmu Nutrisi Ternak Tropis dan Ilmu Pakan. 2(4):217-224.

Rahmah, A.S., Suharti \& Subandi. (2012). Uji Anti bakteri dan Daya Inhibisi Ekstrak Kulit manggis (Garcinia mangostana L.) terhadap Aktivitas XAntin Oksidase yang Diisolasi dari Air Susu Sapi Segar. Universitas Negeri Malang. Malang

Sadiah, I. N., A. Mushawwir. 2015. Mortalitas embrio dan daya tetas itik lokal (Anas sp.) berdasarkan pola pengaturan temperature mesin tetas. Students e-Journal, 4(3), 32-39.

Siregar, R.H., D. Latipudin, A. Mushawwir. 2020. Profil lipid darah ayam ras petelur yang diberi kitosan iradiasi. Jurnal Nutrisi Ternak Tropis dan Ilmu Pakan. 2(1):1-8.

Soeharsono, L. Adriani, E. Hermawan, K. A. Kamil dan A. Mushawwir. 2010. Fisiologi Ternak. Widya Padjajaran. Bandung.

Suwarno, N., A. Mushawwir. 2019. Model Prediksi Metabolit Melalui Jalur Glikogenolisis Berdasarkan Fluktuasi Mikroklimat Lingkungan Kandang Sapi Perah. Jurnal Ilmu dan Industri Peternakan. 5 (2):77-86.

Tanuwiria, U.H., D. Tasrifin, A. Mushawwir. 2020a. Respon gamma glutamil transpeptidase $(\gamma$-gt) dan kadar glukosa sapi perah pada ketinggian tempat (altitude) yang berbeda. J. Ilmu dan Industri Peternakan. 6:25-34.

Tanuwiria, U.H. and A. Mushawwir. 2020b. Hematological and antioxidants responses of dairy cow fed with a combination of feed and duckweed (Lemna minor) as a mixture for improving milk biosynthesis. Biodiversitas.21(10):4741-4746.

Truong-Tran AQ, Ho LH, Chai F, Zelewki PD. 2000. Cellular zinc fluxes and the regulation of apoptosis/gene directed cell death. Journal of Nutrition. 130 (5) : 1459-1466. 